\title{
Fifteen years of microbiological investigation in Opalinus Clay at the Mont Terri rock laboratory (Switzerland)
}

\author{
Olivier X. Leupin ${ }^{1} \cdot$ Rizlan Bernier-Latmani $^{2} \cdot$ Alexandre Bagnoud $^{2}$ • \\ Hugo Moors $^{3} \cdot$ Natalie Leys $^{3} \cdot$ Katinka Wouters $^{3} \cdot$ Simcha Stroes-Gascoyne $^{4}$
}

Received: 21 April 2016/Accepted: 17 December 2016/Published online: 24 February 2017

(C) The Author(s) 2017. This article is published with open access at Springerlink.com

\begin{abstract}
Microbiological studies related to the geological disposal of radioactive waste have been conducted at the Mont Terri rock laboratory in Opalinus Clay, a potential host rock for a deep geologic repository, since 2002. The metabolic potential of microorganisms and their response to excavation-induced effects have been investigated in undisturbed and disturbed claystone cores and in pore(borehole) water. Results from nearly 15 years of research at the Mont Terri rock laboratory have shown that microorganisms can potentially affect the environment of a repository by influencing redox conditions, metal corrosion and gas production and consumption under favourable conditions. However, the activity of microorganisms in undisturbed Opalinus Clay is limited by the very low porosity, the low water activity, and the largely recalcitrant nature of organic matter in the claystone formation. The presence of microorganisms in numerous experiments at the Mont Terri rock laboratory has suggested that excavation activities and perturbation of the host rock combined with additional contamination during the installation of
\end{abstract}

Editorial handling: P. Bossart and A. G. Milnes.

This is paper \#17 of the Mont Terri Special Issue of the Swiss Journal of Geosciences (see Bossart et al. 2017, Table 3 and Fig. 7)

Olivier X. Leupin

olivier.leupin@nagra.ch

1 National Cooperative for the Disposal of Radioactive Waste NAGRA, Hardstrasse 73, 5430 Wettingen, Switzerland

2 École Polytechnique Fédérale de Lausanne EPFL, Route Cantonale, 1015 Lausanne, Switzerland

3 Belgian Nuclear Research Centre SCK·CEN, Boeretang 200, 2400 Mol, Belgium

4 University of Saskatchewan, Saskatoon, Canada experiments in boreholes create favourable conditions for microbial activity by providing increased space, water and substrates. Thus effects resulting from microbial activity might be expected in the proximity of a geological repository i.e., in the excavation damaged zone, the engineered barriers, and first containments (the containers).

Keywords Deep geologic repository for radioactive waste $\cdot$ Subsurface microbiology $\cdot$ Sulphate reduction . Water activity $\cdot$ Hydrogen and nitrate amendments

\section{Introduction}

The concept of deep geological disposal of high level nuclear waste (HLW) is common to most national nuclear energy programs. The radioactive waste will be encapsulated in corrosion-resistant metal containers (e.g., steel, copper, titanium) and buried several hundred meters below ground in a deep geologic repository (DGR), excavated in a stable geological rock formation. Clays are a crucially important part of many DGR designs. On the one hand, clay deposits are being considered as a potential host rock for DGRs in several countries because of the advantageous physical and hydrogeochemical properties of such deposits. On the other hand, bentonite-based barriers and seals are essential components of many DGR designs for a variety of host rocks where they would fulfil multiple specific roles, such as hydraulic, mechanical, thermal, and chemical protection of the containers and ensuring a diffusion-controlled hydrologic environment (e.g., Stroes-Gascoyne et al. 1997; Stroes-Gascoyne and West 1997).

To date, in Europe, four claystone formations have been studied in detail to assess their potential suitability as a host rock for long-lived HLW disposal in a DGR. These are 
Opalinus Clay in Switzerland, Boom- and Ypresian Clay in Belgium and the Callovo-Oxfordian formation and Toarcian argillite, both in France. To investigate engineering-, science-, and safety-relevant issues associated with HLW deep subsurface disposal, underground research laboratories and facilities (URLs and URFs) were established for each of these four clay types (reviewed by Birkholzer et al. 2012). In recent years, a fifth European clay type, Boda Claystone, in Hungary, is being studied for its potential as a host rock for HLW disposal (Lazar and Mathé 2012). Nonclay stable geological formations such as granite, tuff, shale, limestone and salt have also been considered as host rocks for HLW repositories (Delay et al. 2014). In total, 26 URLs/URFs were built worldwide (Blechschmidt and Vomvoris 2012).

Opalinus Clay is the candidate host rock for the safe disposal of radioactive waste in Switzerland. It has been studied mainly at the international Mont Terri Underground Research Laboratory (URL) in Switzerland over the past two decades. As for other host rocks, the integrity of the waste and its containment is critical for the safety of its geological disposal in Opalinus Clay. Thus, in addition to chemical and physical disturbances in the repository, it is important to also consider the possible impact of microorganisms on repository engineered barrier integrity.

This paper reviews the current state of knowledge gleaned from microbiological studies at the Mont Terri rock laboratory, which include explorations of the presence and activity of microorganisms in undisturbed and disturbed claystone, both in solid clay cores and in clay pore(borehole) water. These types of investigations, characterizing the occurrence of microorganisms in Opalinus Clay, their metabolic potential, and their response to repositoryinduced effects, were started at the Mont Terri rock laboratory shortly after its inception 20 years ago.

Particularly, the potential for microbial activity in the immediate vicinity of waste containers in a HLW repository is of interest for the containers' long-term integrity (e.g., Stroes-Gascoyne et al. 2007). Microbiological activity in the near-field (which includes the Engineered Barrier System (EBS) and those parts of the host rock in contact with, or near, the EBS whose properties have been affected by the presence of the repository) may result in:

- Microbially-influenced corrosion (MIC), which could reduce the longevity of the waste containers. MIC would occur through the formation of corrosion-inducing aggressive environments under biofilms or through the production of corrosive metabolites. For the latter, sulphate-reducing bacteria (SRB), that produce sulphide, are of specific concern.

- Microbial gas production (mainly $\mathrm{CO}_{2}$ and $\mathrm{CH}_{4}$ ) may contribute to the build-up of a gas phase in a repository, potentially reducing the effectiveness of the bentonitebased barriers and/or natural barriers.

- Microbial activity may lead to dissolution of minerals in the clay, or leaching of specific elements from those minerals, with possible deleterious effects on the integrity and the effectiveness of this barrier.

- Microbes may adsorb radionuclides released from breached containers and either immobilize these in biofilms; or (motile) microbes may act as colloids to enhance radionuclide migration through unsealed (or incompletely sealed) fractures in the near-field.

- Microbial activity could reduce the gas pressure buildup resulting from anoxic corrosion of the waste containers by oxidizing $\mathrm{H}_{2}$ gas anaerobically, or possibly by the formation of $\mathrm{CH}_{4}$ from $\mathrm{H}_{2}$ and $\mathrm{CO}_{2}$ which would reduce the volume of gas up to four-fold.

There are several ways for microorganisms to become part of a DGR environment. By far, the most likely way is (unavoidable) external contamination, i.e., introduction of microorganisms as a result of anthropogenic activities related to DGR construction. In addition, physico-chemical changes may occur during construction and operation that could stimulate any microorganisms that managed to survive in niches of the geological host rock or engineered barriers.

An extensive study was carried out to investigate the occurrence of indigenous microbes and their community size and structure in an Opalinus Clay core (Mauclaire et al. 2007; Stroes-Gascoyne et al. 2007; Poulain et al. 2008). This core was drilled while applying stringent aseptic techniques to avoid or at least severely minimize external contamination. The aseptic measures employed included (a) steam- and ethanol-cleaned drilling equipment; (b) handling of all equipment with ethanol-treated gloves; and (c) cooling with filtered air and nitrogen (instead of drill water) during drilling. Additionally, latex microspheres (in the size range of microbes) were placed near the drill bit to assess the extent of their intrusion into the core, mimicking possible intrusion of microbes (from the air or nitrogen gas used for cooling) into the core. The results from this study provided limited evidence that a small, viable but most likely largely dormant, microbial community may be present in Opalinus Clay, which was corroborated by a second, more limited set of analyses (Stroes-Gascoyne et al. 2008), on large diameter Opalinus Clay cores, drilled using air-cooling.

Although the earlier microbial characterization of Opalinus Clay (Stroes-Gascoyne et al. 2007, 2008) suggested that unperturbed Opalinus Clay appeared to contain only a small viable microbial community (that is probably metabolically inactive (i.e., dormant cells and spores), due to water, space and nutrient restrictions), it has not been resolved how old such surviving microorganisms might be. The Opalinus Clay 
formation was deposited $174 \mathrm{Ma}$ ago, but survival of microbes (in spore or dormant form) beyond 0.6-3 Ma in ancient geological formations has been disputed (e.g., Susina et al. 2004; Johnson et al. 2007; Takeuchi et al. 2009). Another possible source of indigenous microbes, therefore, could be a much more recent $(<3 \mathrm{Ma})$ intrusion of water along fractures in the Opalinus Clay formation, although studies by Mazurek et al. $(2007,2009)$ have suggested that diffusion alone can explain the hydrogeological features of the Opalinus Clay formation, without having to invoke advective flow. Intrusion of microbes along existing but sealed (i.e., through mineral precipitation) fractures could be another possibility as such mineral-filled fractures could have a slightly higher porosity than the intact clay matrix. Stroes-Gascoyne et al. (2008) discuss these possibilities in more detail.

This review summarizes results from studies that addressed the question of microbial presence and activity in the Opalinus Clay host rock, in borehole water, and in experiments mimicking repository-relevant conditions. First, factors affecting microbial activity in Opalinus Clay in general will be considered followed by microbial detection and activity findings in what is considered as undisturbed Opalinus Clay core and un-amended borehole water. Finally experiments will be reviewed in which borehole water was amended with compounds able to stimulate microbial activity that, depending on the type of radioactive waste, may be unavoidable in a DGR (e.g., organics, $\mathrm{H}_{2}$, nitrate).

\section{General factors restricting microbial activity in Opalinus Clay}

Even if bacteria that would have been trapped during the sedimentation of Opalinus Clay 174 Ma ago had survived, there would be several more reasons why Opalinus Clay is not a favourable environment for microorganisms to thrive.

First, the low porosity of this rock formation is likely to seriously restrict microbial replication and mobility. It has been suggested (Chapelle 1993) that in aquifers, the most consistent predictor of microbial abundance is sediment texture. The diversity of bacteria seems to correlate with sediment type, with the greatest diversity being found in the sandiest sediments. There are probably many mechanisms that contribute to this effect, but the most important factor is the small size of pore throats in clays relative to sands (Chapelle 1993). The average pore throat diameter in clays, as measured by mercury injection porosimetry (MIP), is less than $0.05 \mu \mathrm{m}$. A recent study performed by Hemes et al. (2015) determined, with a combination of X-ray, micro Computer Tomography ( $\mu-\mathrm{CT})$, two dimensional broad ion beam- and focused ion beam scanning electron microscopy (BIB- and FIB-SEM), that the average size of pore throats in Boom Clay is smaller than $0.01 \mu \mathrm{m}$. Senger et al. (2013) reported that most pores in Opalinus Clay are in the meso-pore range $(0.001-0.025 \mu \mathrm{m})$. In sand, on the other hand, average pore throat diameters are much greater, in the 2-20 $\mu \mathrm{m}$ range (Chapelle 1993). Because bacteria in general have diameters ranging from 0.1 to several $\mu \mathrm{m}$, the small pore throats in clay will make it physically impossible for bacteria to move freely. Similarly, MIP analysis of sediments has shown that 90-95\% of the porosity in sands is interconnected, whereas this percentage is much lower in clays. Again, this low pore interconnectivity will additionally restrict the transport of substrates by diffusion to, and the removal of waste products from metabolically active cells. Additionally, the pore size distribution likely also impacts the ability of organisms to proliferate.

Second, the very low amount of available water in Opalinus Clay is another major impediment to microbial life. The free water available to microbes is reduced by interactions with solute molecules (the osmotic effect) and by adsorption to the surface of solids (the matrix effect) (Brown 1990). Microbiologists generally use the term water activity $\left(a_{w}\right)$ to express quantitatively the degree of water availability. The water activity of a solution (or a material containing water) is 0.01 times the relative humidity (in \%) of air in equilibrium with that solution (or material). This corresponds to the ratio of the solution's (or material's) vapour pressure $\left(\mathrm{P}_{\mathrm{sol}}\right)$ to that of pure water $\left(\mathrm{P}_{\text {water }}\right)$ at a fixed temperature:

$\mathrm{a}_{\mathrm{w}}=\mathrm{P}_{\text {sol }} / \mathrm{P}_{\text {water }}$

Low $\mathrm{a}_{\mathrm{w}}$ values are well-known deterrents for bacterial growth in the food industry (e.g., drying, high sugar, or salt concentrations) and the relationship between $\mathrm{a}_{\mathrm{w}}$ and microbial growth limits is well established (Brown 1990). Most Gram-negative bacteria are not able to grow below $\mathrm{a}_{\mathrm{w}}$ values of 0.96, and most Gram-positive bacteria are not able to grow below $\mathrm{a}_{\mathrm{w}}$ values of 0.90 . Select, specialized osmotolerant and halophilic organisms can grow at lower $a_{w}$. With the exception of bacterial endospores, most prokaryotes cannot survive at $\mathrm{a}_{\mathrm{w}}<0.6$, but a few can survive at extremely low $\mathrm{a}_{\mathrm{w}}\left(\mathrm{a}_{\mathrm{w}}\right.$ as low as 0.30) (Lin et al. 2007).

Water activity in clays is determined by the salt content of the pore-water but also by the suction potential, especially in expanding (smectite) clays such as bentonites, which are often part of the EBS in DGR designs. Opalinus Clay contains $40-80 \%$ clay minerals, is a mixture of kaolinite, chlorite, illite and illite/smectite mixed layer phases, and is expected to have significant swelling capacity (swelling pressure perpendicular to stratification is 0.8-1.4 MPa) and suction potential (Ferrari et al. 2014). The latter causes the clay to take up water until it is saturated, at which point the suction potential is zero. The 
water activity measured in an Opalinus Clay core sample with a water content of $8.6 \%$ was 0.962 (Stroes-Gascoyne et al. 2011) and for Opalinus Clay samples with water contents of 7.93 and $7.90 \%, a_{w}$ values were 0.946 and 0.931, respectively (Stroes-Gascoyne et al. 2008).

Third, the apparent lack of easily accessible and easily degradable energy sources in Opalinus Clay may further restrict microbial activity. Opalinus Clay contains organic matter $(\sim 1.5 \%$ w/w (Courdouan et al. 2007 and Courdouan-Metz 2008)) and this carbon could serve potentially as a carbon source and/or electron donor to microorganisms. However, the fact that this organic carbon is present in the rock may indicate that microbes either: (a) are not present in undisturbed Opalinus Clay, (b) are present but not active due to lack of space and available water, or (c) are present but not active due to the inaccessible and/or recalcitrant nature of the organic matter available.

Courdouan et al. (2007) and Courdouan-Metz (2008) concluded that most of the total organic matter in Opalinus Clay is very strongly attached to the mineral phases. They also concluded that synthetic or artificial pore-water (APW) represented the most suitable extractant and yielded extracts most similar to borehole water with respect to low molecular weight organic acids content as well as the size distribution of the hydrophilic dissolved organic matter (DOM). They further found that strictly anoxic conditions during rock sampling, sample storage and analysis (after anoxic extraction) were required to properly evaluate the nature and reactivity of DOM in Opalinus Clay under as close to in situ conditions as possible. Only a very small fraction (about $0.5 \%$ ) of the total organic carbon (TOC) could be extracted into APW under anoxic conditions and about two-thirds of the dissolved organic carbon (DOC) exhibited hydrophilic properties with a molecular size of less than $500 \mathrm{Da}$. About half of the extracted hydrophilic DOC consisted of low molecular weight organic acids such as acetate, propionate, lactate and formate; the other half consisted of higher molecular weight organic matter, while the rest consisted of unknown hydrophobic matter. It is expected that most of the hydrophilic organic matter in Opalinus Clay can be respired or fermented under suitable conditions for microbial activity, i.e., in borehole water where low porosity and low water activity would not be limiting. Whether the extracted hydrophobic matter and the large fraction $(>99 \%)$ of non-extractable TOC can be respired or fermented is not clear.

\section{Microbes in solid Opalinus Clay cores}

Mauclaire et al. (2007) reported that phospholipid fatty acid (PLFA) extracts from Opalinus Clay core samples yielded on average $64 \mathrm{ng}$ of PLFA per $\mathrm{g}$ of dry claystone which, using a standard conversion factor, would translate to the presence of $5 \times 10^{6}$ microbial cells per gram of clay. The PLFA profiles obtained clearly revealed lipid biomarkers specific for anaerobic Gram-negative bacteria and SRB, with lipid profiles indicative of Desulfobulbus and Desulfovibrio.

Stroes-Gascoyne et al. (2007) also studied the occurrence of indigenous microbes, and their population size, community structure and metabolic activity, in Opalinus Clay core from the Mont Terri rock laboratory. A clay core was recovered from a $15 \mathrm{~m}$ long borehole drilled aseptically (as discussed in the introduction) in the exploration gallery of the Mont Terri rock laboratory in early 2004 (known as the PP niche borehole, or BPP-1). Subsamples of this clay core were sent to various microbial laboratories in Europe where the samples were probed for microbial presence using various types of microscopy, molecular biology techniques (PLFA, q-PCR, PCR-DGGE), and cultivation (MPN and enrichment culturing). However, no microbial cells could be identified using acridine orange direct counting (AODC), or fluorescence in situ hybridization (FISH). All attempts to extract PCR-amplifiable DNA from the clay samples failed, and the vast majority of lipids detected by PLFA analysis was indicative of cell debris, rather than viable cells. Cultivation attempts were slightly more successful with a single positive enrichment result for SRB and a few other successful enrichment cultures for aerobic and anaerobic heterotrophs. Stroes-Gascoyne et al. (2007) concluded from these results that the unperturbed Opalinus Clay environment thus may harbour - if at all - a very limited viable microbial population. Renewed efforts to directly extract DNA from the aforementioned samples remained unsuccessful (Poulain et al. 2008). Nonetheless, the limited number of successful enrichment cultures resulted in the isolation and characterization of seven strains, two of which could be identified at genus level, i.e., belonging to Sphingomonas and Alicyclobacillus (Poulain et al. 2008). No further analysis of these strains was performed.

More recently, further attempts to characterize the microbial community in undisturbed Opalinus Clay were made. In particular, a multi-investigator, international round-robin study, in which samples from a single core drilled $50 \mathrm{~m}$ into the rock formation were distributed to four laboratories, was intended to conclusively settle the question of whether viable indigenous microorganisms could be found in Opalinus Clay (Bagnoud et al. 2015b). The study showed that, in some cases, DNA extraction was successful and pointed to a diverse community including Sphingomonas, Procabacteriaceae, Bdellovibrio, Ralstonia, Methylophilaceae, and Rhizobiales. However, there was only limited overlap between the results of the four laboratories despite using the same protocols, suggesting the 
possibility of extensive heterogeneity in biomass distribution and/or contamination in the samples. Finally, the microbial community uncovered from a core ((StroesGascoyne et al. 2007, 2008) from the HT borehole at the Mont Terri rock laboratory revealed the presence of Firmicutes (Moll et al. 2013). More studies are needed to provide irrefutable proof and representative composition of indigenous microorganisms in the undisturbed rock.

\section{Microbes in water from un-amended boreholes in Opalinus Clay}

Because of the very tight nature and low content of water in the Opalinus Clay formation, it would take a long time (months or even years) for a borehole to naturally fill with rock formation- (i.e., pore-) water. Therefore, in most but not all experiments at the Mont Terri rock laboratory, boreholes were filled with artificial pore-water (APW). This section reviews experiments in boreholes that were filled naturally with Opalinus Clay formation water or that were filled with APW, to which subsequently no other microbial substrates were added (other than any contamination introduced into the borehole during the drilling process, or organics leaching from the clay formation into the borehole water).

An experiment (IC-A) carried out at the Mont Terri rock laboratory, originally intended to investigate the corrosion of iron under repository-relevant conditions, inadvertently revealed that providing space is a sufficient condition for bacterial activity in Opalinus Clay. The space created (i.e., the borehole) filled up with Opalinus Clay formation water, creating a propitious environment for microbial activity. The experiment involved a borehole drilled under anoxic but non-sterile conditions that was closed for 10 months prior to the deployment of the module for the corrosion experiment. A borehole water sample was obtained after that time and the sulphide concentration found to be $7.4 \mu \mathrm{M}$, while there was no detectable sulphide upon drilling. This finding suggested the presence of active microorganisms in the borehole water that can reduce sulphate. Subsequently, the microbial community was characterized through metagenomic sequencing and genome-binning. The results revealed a remarkably simple heterotrophic microbial community, mainly composed of two organisms: (1) a Pseudomonas sp., hypothesized to ferment organic macromolecules (either leached from the clay or contributed as contamination during the drilling process) while releasing organic acids and $\mathrm{H}_{2}$; and (2) a sulphate-reducing member of the Peptococcaceae, hypothesized to oxidize the organic acids to carbon dioxide while reducing sulphate (Bagnoud et al. 2015a).

Additionally, a survey of the microbial communities in 23 water samples from 8 boreholes across the Mont Terri rock laboratory was conducted which identified 13 organisms that were present in all boreholes (Bagnoud et al. 2016a). Table 1 shows the contribution of each of the 13 microorganisms ubiquitous in Mont Terri rock laboratory borehole waters to the microbial communities in four anoxic boreholes (BIC-A1, BPC-2, BDR-T1/1 and BDR$\mathrm{T} 1 / 2)$. For instance, ubiquitous microbes represented more than $92 \%$ of the microbial community in BIC-A1, the borehole in which the IC-A experiment was conducted.

\section{Microbes in water from amended boreholes in Opalinus Clay}

This section considers studies in boreholes filled with APW to which amendments were made, either deliberately or inadvertently, affecting microbial activity. Amendments included an organic compound, hydrogen gas or nitrate.

\subsection{Organic compound: Glycerol}

Early (2003-2006) microbial investigations of Opalinus Clay borehole water from the in situ Porewater Chemistry (PC) experiment using DAPI (4',6-diamidino-2-phenylindole) staining, revealed total cell counts that varied from $6 \times 10^{3}$ to $2 \times 10^{6}$ cells $/ \mathrm{mL}$ (Battaglia and Gaucher 2003; Ishii 2004; Mauclaire and McKenzie 2006a, b; Mauclaire et al. 2006). Subsequent cultivation and molecular studies of clay and water samples from the PC experiment indicated a diverse and active microbial community in PC borehole water and adjacent clay (accessible in the overcore of the PC experiment) (Stroes-Gascoyne et al. 2011). Sulphate reduction in this experiment was evident with a distinct smell, blackening and visually observable pyrite (and mackinawite) precipitation in sample lines as confirmed by X-Ray Diffraction analysis (Stroes-Gascoyne et al. 2008). Cell counts and quantitative cultivation results were as high as $7 \times 10^{8}$ cells $\mathrm{mL}^{-1}$ in these samples. Most probable number (MPN) and agar plate cultivation allowed the enumeration of various physiological groups of microorganisms, including aerobic and anaerobic heterotrophs, sulphate-reducing bacteria, nitrate-utilizing and nitrate-reducing bacteria, iron-reducing bacteria, anaerobic lithotrophs, and methanogens. DNA extractions from PC water, agar plate pure cultures, and enrichment cultures were subjected to quantitative real-time PCR using universal primers for the bacterial and archaeal 16S rRNA genes. The amplicons were separated by DGGE, isolated from the electrophoresis matrix, re-amplified, and sequenced. In addition, SRB were quantified by targeting the dissimilatory sulphite reductase $(d s r \mathrm{~A})$ gene, while methanogenic Archaea were quantified by targeting the methyl coenzyme M reductase gene ( $m c r \mathrm{~A})$. Using a $97 \%$ 
Table 1 Contribution of ubiquitous Operational Taxonomic Units (OTUs) to the microbial communities from borehole water collected from four anoxic boreholes in the Opalinus Clay at the Mont Terri rock laboratory. Taxonomic affiliation and expected metabolism type are indicated. Total contribution of the 13 ubiquitous OTU's to each borehole community is indicated for each sample (last row). Colours indicate the fraction of the OTU's in each borehole (green 0.5-1.0; yellow 0.01-0.5; red 0-0.01) (Modified from Bagnoud (2015))

\begin{tabular}{|c|c|c|c|c|c|c|c|c|}
\hline & \multicolumn{5}{|c|}{ Proportion in samples } & \multirow[b]{2}{*}{ Taxonomic affiliation } & \multirow[b]{2}{*}{ Metabolism type } & \multirow[b]{2}{*}{ Reference } \\
\hline & OTU \# & BIC-A1/1 & BPC-2/1 & BDR-T1/1 & BDR-T1/2 & & & \\
\hline & 0 & $1.25 \mathrm{E}-04$ & 0.5124 & $1.48 \mathrm{E}-04$ & $1.08 \mathrm{E}-04$ & Desulfocapsa & Sulfate-reducing bacteria & Kuever et al. , 2005 \\
\hline & 1 & 1.10E-04 & 7.05E-05 & $8.12 E-05$ & 7.19E-05 & Novispirillum & $\mathrm{O}_{2}$ and $\mathrm{NO}_{3}^{-}$respiring bacteria & Yoon et al. , 2007 \\
\hline & 2 & 0.2594 & 0.0056 & 0.0007 & 0.0006 & Pseudomonas & $\mathrm{O}_{2}$ and $\mathrm{NO}_{3}^{-}$respiring bacteria & Moore et al. , 2006 \\
\hline & 3 & 7.05E-05 & 1.06E-04 & 4.43E-05 & $5.03 E-05$ & Rhodobacteraceae & Metabolically diverse & Garrity et al. , 2005 \\
\hline & 4 & $1.57 \mathrm{E}-05$ & $5.28 \mathrm{E}-05$ & 7.38E-06 & 4.31E-05 & Xanthomonadaceae & $\mathrm{O}_{2}$ respiring bacteria & Saddler and Bradbury, 2005 \\
\hline & 5 & $1.57 \mathrm{E}-05$ & $5.28 \mathrm{E}-05$ & 0.5684 & 0.5258 & Pleomomhomonas & $\mathrm{O}_{2}$ respiring or fermenting bacteria & Xie and Yokota, 2005 \\
\hline & 6 & 0.0416 & 0.0095 & 0.2667 & 0.2824 & Desulfosporosinus & Sulfate-reducing bacteria & Spring and Rosenzweig, 2006 \\
\hline & 7 & 0.0165 & 1.76E-05 & $1.48 \mathrm{E}-05$ & $0.00 \mathrm{E}+00$ & Desulfotomaculum & Sulfate-reducing bacteria & Auello et al. , 2013 \\
\hline & 9 & 0.5717 & 0.0184 & 0.0083 & 0.0079 & Desulfotomaculum & Sulfate-reducing bacteria & Auello et al. , 2013 \\
\hline color scale & 13 & $7.84 \mathrm{E}-06$ & $1.76 \mathrm{E}-05$ & 7.38E-06 & 2.87E-05 & Methyloversatilis & Metabolically diverse & Kalyuzhnaya et al., 2006 \\
\hline 1.0000 & 15 & $3.92 \mathrm{E}-05$ & 0.0033 & $8.86 \mathrm{E}-05$ & 2.87E-05 & Pseudomonas & $\mathrm{O}_{2}$ and $\mathrm{NO}_{3}^{-}$respiring bacteria & Moore et al. , 2006 \\
\hline 0.0100 & 17 & $7.84 \mathrm{E}-06$ & 0.0018 & 1.48E-05 & 7.19E-06 & Thiobacillus & $\mathrm{O}_{2}$ and $\mathrm{NO}_{3}^{-}$respiring bacteria & Kelly et al. , 2005 \\
\hline \multirow[t]{2}{*}{0.0000} & 36 & 0.0317 & 0.1268 & $0.00 \mathrm{E}+00$ & 4.66E-04 & Desulfosporosinus & Sulfate-reducing bacteria & Spring and Rosenzweig, 2006 \\
\hline & SUM & 0.9213 & 0.6781 & 0.8446 & 0.8175 & & & \\
\hline
\end{tabular}

cut-off level of 16S rRNA sequence identity against database references, PC borehole water included Pseudomonas stutzeri, Bacillus licheniformis, Desulfosporosinus sp., and Hyphomonas, while overcore samples included Pseudomonas stutzeri, three species of Trichococcus, Nostocoida limicola, Caldanaerocella colombiensis, Geosporobacter subterrenus, Kocuria palustris, and Desulfosporosinus $\mathrm{sp}$.

Although the origin of the observed microorganisms in the PC experiment is unknown, it is likely that at least a fraction was introduced for instance through the use of non-sterilized APW during the course of the experiment, despite strict precautions taken during the actual drilling of the PC borehole to avoid microbial contamination (as discussed by Stroes-Gascoyne et al. 2007). The PC-experiment also differed from other experiments by the virtual absence of metal construction parts (to avoid the influence of metals on redox conditions in the borehole) and the use instead of many different kinds of plastic and polymer materials. After a careful study of the possible leaching of organic carbon into the PC water from these materials, De Cannière et al. (2011) concluded from their analysis results, as well as from geochemical modelling calculations, that the most likely primary organic $\mathrm{C}$ source fueling the microbial activity in the PC experiment was glycerol released from the polymeric gel filling in the reference electrodes used. De Cannière et al. (2011) further concluded that other sources, such as acetone used to clean some equipment, may also have contributed to microbial processes, but only to a minor extent.

Similarly, the microbial activity observed during an in situ diffusion experiment at the Mont Terri rock laboratory that was not designed to stimulate the microbial community (the DR experiment; Leupin et al. 2012), prompted an investigation into the source of carbon supporting the microbial biomass. One of the possible carbon sources suspected in this experiment was again glycerol leaking from an online $\mathrm{pH}$-probe. The experiment was designed to study the diffusion of tracers into the Opalinus Clay formation and the probe was used to monitor the $\mathrm{pH}$ of the circulating borehole water in the experiment (Leupin et al. 2012). Laboratory incubations with borehole water from the DR experiment and glycerol amendments were performed to investigate the hypothesis that glycerol was fuelling the microbial community (Frutschi and BernierLatmani 2010a, b). Clear stimulation of microbial activity was observed in the presence of glycerol. Sulphate concentrations were not analysed, but a sulphide smell was associated with the cultures, suggesting that glycerol was an electron donor in sulphate reduction (Frutschi and Bernier-Latmani (2010a, b)).The compound served either as an electron donor for respiration or as a fermentative substrate.

A detailed microscopic analysis of the laboratory enrichment cultures with glycerol evidenced that the microbes stimulated by glycerol included endospore formers (Frutschi and Bernier-Latmani 2010a, b). Cells were efficiently stained with DAPI, suggesting the presence of cytoplasmic DNA. The 16S rRNA gene clone library that was obtained from the laboratory enrichment cultures with glycerol was remarkable in its lack of diversity. Essentially, all the clones sequenced from the clone library were representatives of the genus Desulfosporosinus, a Gram positive bacterium known to form 
endospores. The Desulfosporosinus species from this experiment corresponds to OTU 6 (Operational Taxonomic Unit 6) in Table 1 (Bagnoud 2015). The type strains of the species Desulfosporosinus lacus, one of the best matches from the clone library, has indeed been reported to use glycerol as a carbon source and electron donor in the presence of sulphate (Ramamoorthy et al. (2006)). However, it can also grow autotrophically with $\mathrm{H}_{2}$ and $\mathrm{CO}_{2}$, which is of relevance for DGR safety considering that $\mathrm{H}_{2}$ and $\mathrm{CO}_{2}$ gases will be produced in a DGR by anaerobic corrosion of steel and degradation of organics, respectively. Thus, Desulfosporosinus species were predominant in the microbial community from the DR experiment borehole water, further stimulated by the addition of glycerol in the laboratory. Therefore, it was concluded that Desulfosporosinus species were most likely the main SRB able to utilize glycerol as an electron donor for sulphate reduction in the DR experiment. In fact, Desulfosporosinus strains (corresponding to OTU 6 in Table 1) were also identified in the PC experiment discussed above and repeatedly identified in various borehole water samples of the Bitumen-Nitrate (BN) experiment.

\subsection{Hydrogen}

An experiment (MA) was devised to investigate the impact of $\mathrm{H}_{2}$ on the microbial community in Opalinus Clay (see Fig. 1). In particular, the salient question was whether the microbial community would be complex enough to allow carbon biogeochemical cycling. MA entailed the repeated (approximately weekly) injection of $\mathrm{H}_{2}(\mathrm{~g})$ into the $\mathrm{BRC}-3$ borehole filled with sterile APW at the Mont Terri rock laboratory over a period of 500 days (Bagnoud 2015; Bagnoud et al. 2016a, b). While the borehole was initially aerobic, dissolved oxygen (DO) quickly decreased after initiation of the $\mathrm{H}_{2}$ injection and, after approximately a month, DO had fallen below the detection limit. Subsequently, the concentration of ferrous iron [Fe(II)] increased, followed by a rapid decrease and the establishment of steady sulphate-reducing conditions starting approximately at day 50. Several approaches were used for the detailed study of the microbial community. First, amplification of the $16 \mathrm{~S}$ rRNA gene followed by sequencing of 60 samples taken over 500 days yielded a detailed view of the evolution of the microbial community as a function of time and chemical conditions (Bagnoud et al. 2016a). During the oxygen-reducing phase, more than $50 \%$ of the microbial community was represented by Gamma-proteobacteria pertaining to the genus Pseudomonas and the family Xanthomonadaceae, while the rest were mostly Alpha-proteobacteria such as species from the genus Novispirillum and the family Rhodobacteraceae. The latter two persisted throughout the 500 days of the experiment. While these organisms clearly were instrumental in consuming oxygen by reduction with $\mathrm{H}_{2}$, they are unlikely to be relevant for repository conditions as anoxic conditions are expected to be established rapidly. Interestingly, the composition of the microbial community during the $\mathrm{Fe}(\mathrm{II})$ production phase (presumed to be a microbial iron-reduction phase) was very similar to that of the sulphate-reducing phase, suggesting that the sulphatereducing bacteria may have reduced $\mathrm{Fe}$ (III) before sulphate reduction occurred. Fe(III) was presumably derived from the oxidation of pyrite in the borehole while it was open to the atmosphere for several years. For the majority of the duration of the experiment, a Gram-negative Delta-proteobacterium, belonging to the order Desulfobacterales and identified by $16 \mathrm{~S}$ rRNA sequencing to belong to the genus Desulfocapsa, was the most abundant microorganism identified. In addition, Gram-positive SRB were also present throughout.

In order to better unravel the role of the various microorganisms in the oxidation of $\mathrm{H}_{2}$ and the reduction of sulphate, as well as to attempt the reconstruction of the metabolic web in the borehole, a combined metagenomic and metaproteomic study was carried out (Bagnoud 2015; Bagnoud et al. 2016a). After assembly of the sequencing data for 16 samples, a binning approach was used for assembled contigs, and individual genomes were reconstructed in silico. In particular, seven organisms were identified with sufficient protein to infer their actual metabolic activity in the borehole water. Two autotrophic microorganisms were identified: a member of the Desulfobulbaceae family (corresponding to Desulfocapsa from the $16 \mathrm{~S}$ rRNA gene sequencing) and a member of the Rhodospirillaceae family (corresponding to Novispirillum from the $16 \mathrm{~S}$ rRNA gene sequencing). Metaproteomic data showed clearly that the Desulfobulbaceae strain actively oxidized $\mathrm{H}_{2}$, reduced sulphate and fixed $\mathrm{CO}_{2}$ while the Rhodospirillaceae strain appeared to also use $\mathrm{H}_{2}$ as an electron donor while fixing $\mathrm{CO}_{2}$, but the electron acceptor remained elusive. The former uses the reductive acetyl$\mathrm{CoA}$ pathway for $\mathrm{CO}_{2}$ fixation, while the latter uses the Calvin-Benson-Bassham cycle for $\mathrm{CO}_{2}$ fixation.

Further, a Hyphomonas species was identified and interpreted to be a fermentative organism, utilizing, most likely, microbial necromass as a source of carbon and energy, and releasing fatty acid intermediates (e.g., acetate) that could be used by other heterotrophic microorganisms in the community (note that Hyphomonas sp. was also identified in the PC experiment, Stroes-Gascoyne et al. (2011)). In particular, four heterotrophic SRB were identified and exhibited active sulphate reduction, presumably fuelled by the oxidative acetyl-CoA pathway utilizing acetate (and potentially other organic acids). Three of the four SRB were Firmicutes, while one was a species from 


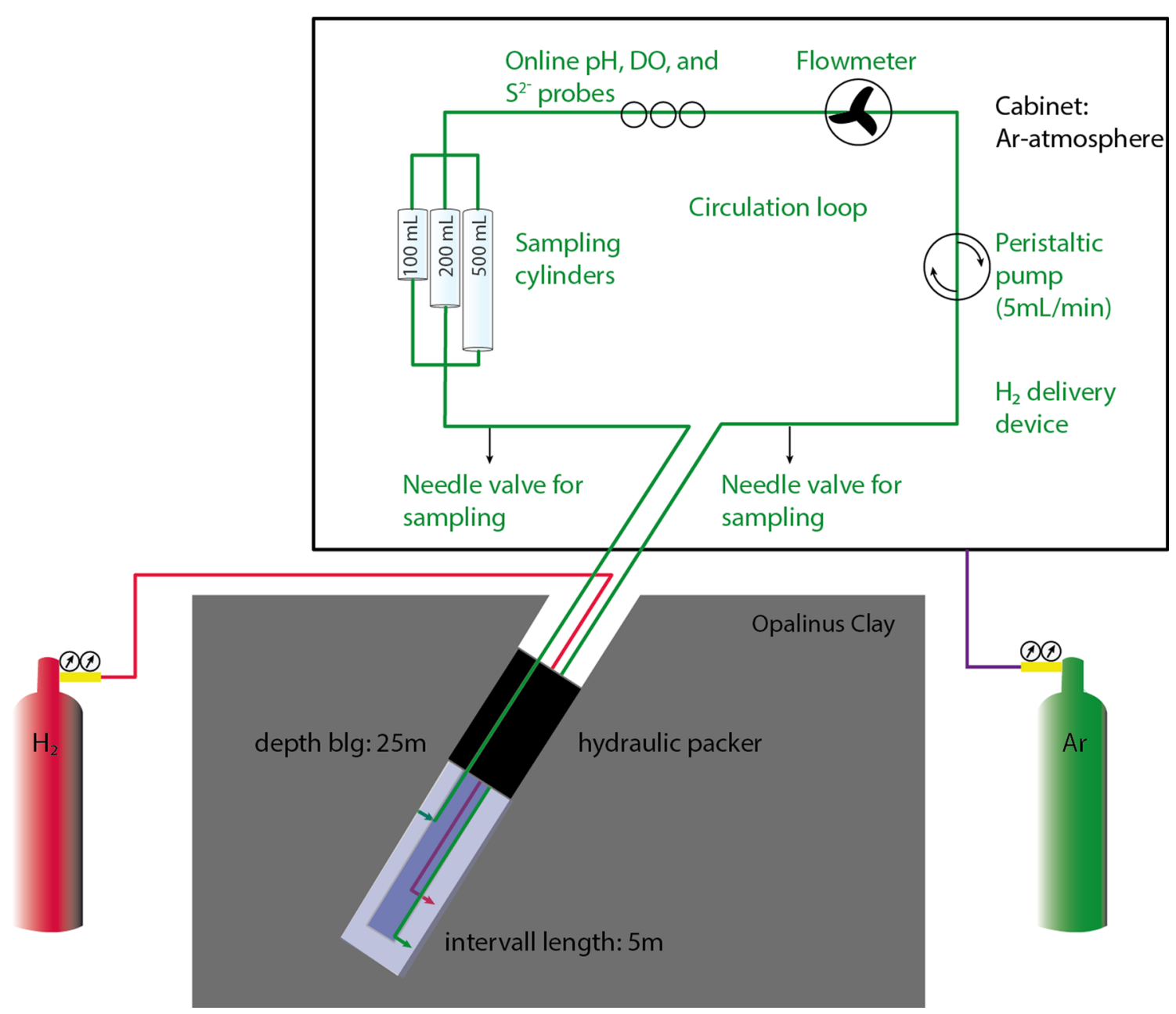

Fig. 1 Schematic of the setup of the MA experiment at the Mont Terri Research Laboratory

the genus Desulfatitalea, a Deltaproteobacterium. Overall, the metabolic web reconstructed in the borehole water (Bagnoud et al. 2016a) comprised autotophic growth dependent on $\mathrm{H}_{2}$ as a source of energy for $\mathrm{CO}_{2}$ fixation, (suspected) fermentation of necromass, and the oxidation of organic acids back to $\mathrm{CO}_{2}$, closing the carbon loop. From the experiment, it was evident that $\mathrm{H}_{2}$ consumption was rapid and that the presence of this energy source would support a thriving and active sulphate-reducing microbial community (Bagnoud et al. 2016a, b).

Both autotrophic organisms, the Desulfobulbaceae (which correspond to OTU 0 in Table 1) and the Rhodospirillaceae (which correspond to OTU 1 in Table 1) members, as well as a heterotrophic SRB, a Desulfotomaculum member (which corresponds to OTU 7 in Table 1), were identified in the water of all eight boreholes investigated by Bagnoud (2015). Moreover, the fermentative organism belonging to Hyphomonas genus, was detected in seven of the eight boreholes investigated by Bagnoud (2015).

\subsection{Nitrate}

The Bitumen-Nitrate-Clay interaction (BN) experiment was installed in situ in the Opalinus Clay at the Mont Terri rock laboratory, with the aim to clarify the (bio)chemical impact of a spreading nitrate and organic plume on the properties and safety of a potential DGR in clay host rock (Bleyen et al. 2017). In the BN-experiment, the transport and reactivity of nitrate is studied inside saturated packedoff and anoxic intervals, filled with APW, constructed in a borehole drilled in the Opalinus Clay. The current BNexperiment set-up does not take any backfill or cement matrix into account but investigates first a purely aquatic environment in the form of a water-filled borehole. As such, the current BN-experimental setup allows free movement of dissolved macro- and micro-nutrients, electron donors and acceptors, and provides microorganisms a physically non-restricted environment (e.g., open space, maximal $\mathrm{a}_{\mathrm{w}}$ ). The in situ microbial reduction of added nitrate and/or nitrite is being investigated, in the absence 
and/or presence of added electron donors relevant for the disposal concept of nitrate-containing bituminized intermediate level radioactive waste (ILW). The results of the $\mathrm{BN}$ tests indicate that microbiological nitrate reduction can occur with electron donors naturally present in Opalinus Clay (e.g., pyrite, DOM, fermentation products, microbiological necromass), but that the rate of nitrate reduction can increase by a factor of 20-70 when an additional electron donor (acetate or hydrogen) is added to the borehole.

The observed evolution of the chemical composition of the borehole water correlated well with the detected shifts in the microbiological populations (analysed by 16S rRNA gene sequencing) observed in the borehole solution. The addition of nitrate inhibited the naturally slowly ongoing in situ microbiological sulphate reduction and induced a shift in the microbial community, with nitrate- and nitritereducing microorganism becoming more dominant. These nitrate- and nitrite-reducing microorganism included strains from the genera Pseudomonas, Cupriavidus, Pelomonas, Undibacterium, Acidovorax, Phenylobacterium, Brevundimonas and Corynebacterium. Once nitrate (and/or nitrite) was completely reduced, the chemical composition and the microbiological community of the interval solution gradually shifted back towards their original state of slow sulphate reduction, showing strains from the genera Pseudomonas (Table 2, OTU 2), Gracillibacter, and Desulfosporosinus (Table 2, OTU 6). This evolution is in agreement with thermodynamic succession in usage of dissolved electron acceptors: nitrate is a more favourable electron acceptor than sulphate, and when nitrate is present it will be used preferentially until depletion, after which sulphate is again next in line to be used as electron acceptor. More details of the $\mathrm{BN}$ experiment and specifics of the genomic analysis of the microbial communities encountered during this multi-year, on-going experiment are reported in Bleyen et al. (2017) and by Moors et al. (2012, 2013, 2015).

\section{Conclusion from almost 15 years of microbial investigations in Opalinus Clay}

It has been considered that a microbial community potentially indigenous to the host rock may become part of a DGR environment. An indigenous community is not necessarily a community that is as ancient as the host rock deposit itself. Natural geological processes such as geological movement, landslides, the formation of cracks and fissures, infiltration of foreign water from aquifers or as a result of flooding, are just a few of the normal processes that can introduce microorganisms into rock formations, and be the source of a more recent or present day indigenous community. However, it has been impossible so far to demonstrate unambiguously the existence of a viable microbial community originating from the Opalinus Clay itself at the Mont Terri rock laboratory. In addition, physico-chemical evidence rather suggests that the ancient undisturbed Opalinus Clay is far too restrictive (in pore size and water activity) to host microbiological life, except perhaps in areas where those restricting factors are less severe (e.g., fractures). Nevertheless, there is the undisputable involvement of microorganisms in almost every experiment or borehole in the Mont Terri rock laboratory. This indicates that there are, besides possibly the claystone itself, likely many other sources that could introduce microbes in the Mont Terri rock laboratory. The most likely way is the unavoidable external contamination or introduction of microorganisms as a result of anthropogenic activities related to the Mont Terri rock laboratory construction and/or experiment installation. The Mont Terri rock laboratory consists of tunnels drilled and constructed over an extended period of time. During construction, no precautions were taken to avoid microbiological contaminations or the use of (petro)chemicals or materials beneficial to microbial life. As a result, ubiquitous contamination, resulting in colonization of omnipresent aerobic and/or facultative anaerobic species (such as, for example, Pseudomonas or even Pleomorphomonas spores), of the tunnel surface is likely. Furthermore, constructing an underground rock laboratory implies anthropogenic activities that may induce physicochemical changes in the rock environment that might stimulate dormant microorganisms that managed to survive in certain niches of the rock or engineered barriers. Simply drilling a borehole opens up space and, even if no water is used during drilling, drainage of pore-water into that space is sufficient to initiate the establishment of an active microbiological community (c.f., the borehole of the corrosion experiment). In addition, the use of non-sterilized APW in many experiments may have enhanced microbial communities. Microbial metabolic activity can be further enhanced by the presence of exogenous electron donors such as $\mathrm{H}_{2}$ (from anaerobic corrosion of metals), organics such as glycerol (leaked from electrodes used for monitoring $\mathrm{pH}$ ), and electron acceptors such as nitrate, in addition to naturally present electron donors, acceptors and organics in the Opalinus Clay. The diversity of the observed microbial communities present in Opalinus Clay borehole water can be surprisingly rich and a specific group of microorganisms is found ubiquitously within the whole Mont Terri rock laboratory, as shown in Table 1 (modified from Bagnoud 2015).

The impact of microbial activity on repository evolution remains incompletely constrained but the considerable research effort that has been invested in this topic has borne fruit. First, it is clear that $\mathrm{H}_{2}$, produced by anaerobic 
corrosion in a HLW DGR, can be readily consumed by bacteria, provided that space and water are present. For repositories that would contain other types of waste, such as bituminized nitrate-containing ILW or abundant organic matter-containing low level radioactive waste (LLW), the availability of additional electron donors and acceptors in these wastes is a further factor that can enhance microbial activity. While this activity can have both positive and negative effects, the full impact is not completely understood and requires considerably more study in the future.

Overall, the results collected to date and discussed here lead to the hypothesis that microorganisms will most likely have an impact on the environment in a repository in Opalinus Clay. Whether this microbial impact is detrimental or beneficial for a given DGR concept for HLW, ILW or LLW, has to be investigated further.

\section{Future investigations}

Safety assessments for future DGRs disposing of a variety of nuclear waste types will require a clearer understanding of the potential role of microbial communities in a HLW repository. In particular, quantification of microbial effects is needed in order to estimate, for instance, the actual contribution of MIC to the overall corrosion rates of containers in a DGR.

Much remains to be learned about the capacity of microorganisms to alter the minerals that make up the engineered barriers (i.e., those contained in Opalinus Clay and bentonite). Biofilm dwellers are the most likely candidates to catalyse such processes, which almost certainly would take place at interface regions because of the restrictive nature of the intact clay matrix. Nakano and Kawamura (2010) estimated the extent of corrosion of compacted bentonite by microbes in a biofilm on the surface of the bentonite through a conceptual model based on microbial growth dynamics. The model used energy conservation between the Gibbs free energy of formation of products from the elements of bentonite and the energy required for growth and maintenance of micro-organisms. This model predicted a mean population of micro-organisms of $10^{6}-10^{7}$ cells $/ \mathrm{cm}^{3}$ on the bentonite surface, with a biofilm thickness of $5-10 \mu \mathrm{m}$. The microbial corrosion depth was estimated to be in the range of less than $0.2-5.3 \mathrm{~mm}$ per 100,000 years, provided the bentonite density was $1600 \mathrm{~kg} / \mathrm{m}^{3}$ while the corrosion depth varied inversely with bentonite density.

In addition, investigations of the potential for methanogenesis in a DGR are needed in order to evaluate whether methane could be produced by biological means from the degradation of organic compounds present in ILW and LLW that will also be placed in a specially designed geological repository.

From a purely scientific point of view, further microbial investigations to unambiguously prove or disprove the existence of an indigenous, viable microbial community in Opalinus Clay should focus on obtaining DNA from pristine cores. Although such studies would, in principle, not add to the understanding of microbial effects in a DGR, not finding an indigenous population would corroborate strongly the unsuitability of the intact Opalinus Clay matrix to support a viable community, while finding an indigenous viable population may shed further light on possible geological events that could have introduced such a community in Opalinus Clay.

Acknowledgements We thank the Swisstopo crew of St. Ursanne for providing excellent working conditions in the Mont Terri rock laboratory. We also thank the many international researchers involved in the work reviewed in this paper.

We further like to express our gratitude to Professor Darren R. Korber (University of Saskatchewan) and Professor Judy McKenzie (ETH Zürich) for a useful and detailed review.

Open Access This article is distributed under the terms of the Creative Commons Attribution 4.0 International License (http://crea tivecommons.org/licenses/by/4.0/), which permits unrestricted use, distribution, and reproduction in any medium, provided you give appropriate credit to the original author(s) and the source, provide a link to the Creative Commons license, and indicate if changes were made.

\section{References}

Auello, T., Ranchou-Peyruse, A., Ollivier, B., \& Magot, M. (2013). Desulfotomaculum spp. and related Gram-positive sulfatereducing bacteria in deep subsurface environments. Frontiers in Microbiology, 4, 362.

Bagnoud, A. (2015). Microbial metabolism in the deep subsurface: 1 case study of Opalinus Clay. Ph.D. dissertation, Ecole Polytechnique Fédérale de Lausannne, Lausanne, Switzerland, p 189

Bagnoud, A., Cherkouk, A., Sergeant, C., Korber, D., \& BernierLatmani, R. (2015b). Microbiological analysis of the cores of the BFE-A11 drill cores at the Mont Terri Rock Laboratory-Final report. Mont Terri Technical Note, TN 2014-101, 21 pp. Federal Office of Topography (swisstopo), Wabern, Switzerland. http:// www.mont-terri.ch

Bagnoud, A., Chourey, K., Hettich, R. L., de Bruijn, I., Andersson, A. F., Leupin, O. X., Schwyn, B., \& Bernier-Latmani, R. (2016a). Reconstructing a hydrogen-driven microbial metabolic network in Opalinus Clay rock. Submitted to Nature Communications. (ISSN: 2041-1723).

Bagnoud, A., de Bruijn, I., Andersson, A. F., Diomidis, N., Leupin, O. X., Schwyn, B., et al. (2015a). A minimalistic microbial food web in an excavated deep subsurface clay rock. FEMS Microbiology Ecology. doi:10.1093/femsec/fiv138.

Bagnoud, A., Leupin, O. X., Schwyn, B., \& Bernier-Latmani, R. (2016b). Rates of microbial hydrogen oxidation and sulfate reduction in Opalinus Clay rock. Applied Geochemistry, 72, $42-50$. 
Battaglia, F., \& Gaucher, E. (2003). Mont Terri Project porewater chemistry (PC) experiment: Microbial characterization and particle transport. Mont Terri Technical Note, TN 2003-23, 26 pp. Federal Office of Topography (swisstopo), Wabern, Switzerland. http://www.mont-terri.ch

Birkholzer, J., Houseworth, J., \& Tsang, C. F. (2012). Geologic Disposal of High-Level Radioactive Waste: Status, Key Issues, and Trends. Annual Review of Environment and Resources, 37, 79-106.

Blechschmidt, I., \& Vomvoris, S. (2012). Underground research facilities and rock laboratories for the development of geological disposal concepts and repository systems. In J. Ahn, M. J. Apted, (Eds.), Geological repository systems for safe disposal of spent nuclear fuels and radioactive waste. Woodhead Publishing Limited

Bleyen, N., Smets, S., Small, J., Moors, H., Leys, N, Albrecht, A., de Cannière, P., Schwyn, B., Wittebroodt, C., \& Valcke, E. (2017). Impact of the electron donor on in situ microbial nitrate reduction in Opalinus Clay. Results from the Mont Terri rock laboratory (Switzerland). Swiss Journal of Geosciences, 110 (this issue).

Brown, A. D. (1990). Microbial water stress physiology. Principles and perspectives (328 pp.). John Wiley \& Sons.

Bossart, P., Bernier, F., Birkholzer, J., Bruggeman, C., Connolly, P., Dewonck, S., Fukaya, M., Herfort, M., Jensen, M., Matray, J-M., Mayor, J. C., Moeri, A., Oyama, T., Schuster, K., Shigeta, N., Vietor, T., Wieczorek, K. (2017). Mont Terri rock laboratory, 20 years of research: introduction, site characteristics and overview of experiments. Swiss Journal of Geosciences, 110. doi:10.1007/ s00015-016-0236-1 (this issue).

Chapelle, F. H. (1993). Ground-water Microbiology and Geochemistry (496 pp.). John Wiley \& Sons

Courdouan, A., Christl, I., Wersin, P., \& Kretzschmar, R. (2007). Nature and reactivity of dissolved organic matter in the Opalinus Clay and Callovo-Oxfordian Formations. In: Proc. Clays in Natural and Engineered Barriers for Radioactive Waste Confinement, Lille, France.

Courdouan-Metz, A. (2008). Nature and reactivity of dissolved organic matter in clay formations evaluated for the storage of radioactive waste. Ph.D. dissertation. Swiss Federal Institute of Technology in Zurich, Zurich, Switzerland, 114 pp.

De Cannière, P., Schwarzbauer, J., Höhener, P., Lorenz, G., Salah, S., Leupin, O. X., et al. (2011). Biogeochemical processes in a clay formation in situ experiment: Part $\mathrm{C}$-Organic contamination and leaching data. Applied Geochemistry, 26, 967-979.

Delay, J., Bossart, P., Ling, L. X., Blechschmidt, I., Ohlsson, M., Vinsot, A., et al. (2014). Three decades of underground research laboratories: what have we learned? Geological Society, London, Special Publications, 400, 7-32.

Ferrari, A., Favero, V., Marschall, P., \& Laloui, L. (2014). Experimental analysis of the water retention behaviour of shales. International Journal of Rock Mechanics and Mining Sciences, 72, 61-70.

Frutschi, M., \& Bernier-Latmani, R. (2010a). DR Experiment: Evaluation of the role of glycerol in microbial growth at the Mt Terri rock laboratory. Mont Terri Technical Note, TN 2009-35, 21 pp. Federal Office of Topography (swisstopo), Wabern, Switzerland. http://www.mont-terri.ch

Frutschi, M., \& Bernier-Latmani, R. (2010b). PC (porewater chemistry) Experiment: porewater microbial community stimulated by glycerol at the Mt Terri rock laboratory-Final report. Mont Terri Technical Note, TN 2009-36 26 pp. Federal Office of Topography (swisstopo), Wabern, Switzerland. http://www. mont-terri.ch

Garrity, G. M., Bell, J. A., \& Lilburn, T. (2005). Family VII. Rhodobacteraceae. In, G. M. Garrity, D. J. Brenner, N. R. Krieg,
J. T. Staley, (Eds.), Bergey's Manual of Systematic Bacteriology. New-York.

Geesey, G. G. (1993). A Review of the potential for microbially influenced corrosion of high level nuclear waste containers. Center for Nuclear Waste Regulatory Analyses Report, CNWRA 93-014.

Hemes, S. S., Desbois, G., Urai, J. L., Schröppel, B., \& Schwarz, J. O. (2015). Multi-scale characterization of porosity in Boom Clay (HADES-level, Mol, Belgium) using a combination of X-ray $\mathrm{m}-\mathrm{CT}, 2 \mathrm{D}$ BIB-SEM and FIB-SEM tomography. Microporous and Mesoporous Materials, 208, 1-20.

Ishii, K., (2004). Pore water chemistry (PC) experiment: quantification (and qualification) of microbial communities. Mont Terri Technical Note, TN 2004-76, 19 pp. Federal Office of Topography (swisstopo), Wabern, Switzerland. http://www.mont-terri. ch

Johnson, S. S., Hebsgaard, M. B., Christensen, T. R., Mastepanov, M., Nielsen, R., Munch, K., et al. (2007). Ancient bacteria show evidence of DNA repair. Proceedings of the National Academy of Sciences, 104, 14401-14405.

Kalyuzhnaya, M. G., Marco, P. D., Bowerman, S., Pacheco, C. C., Lara, J. C., Lidstrom, M. E., et al. (2006). Methyloversatilis universalis gen. nov., sp. nov., a novel taxon within the Betaproteobacteria represented by three methylotrophic isolates. International Journal of Systematic and Evolutionary Microbiology, 56, 2517-2522.

Kelly, D. P., Wood, A. P., Stackebrandt, E., Brenner, D. J., Krieg, N. R., \& Staley, J. T. (2005). Thiobacillus. In G. Garrity (Ed.), Bergey's Manual of Systematic Bacteriology (pp. 764-769). New-York: Springer.

Kuever, J., Rainey, F. A., \& Widdel, F. (2005). Desulfocapsa. In G. M. Garrity, D. J. Brenner, N. R. Krieg, \& J. T. Staley (Eds.), Bergey's Manual of Systematic Bacteriology (pp. 992-994). New-York: Springer.

Lazar, K., \& Mathé, Z. (2012). Claystone as a potential host rock for nuclear waste storage. Chapter 4 Clay minerals in nature, their characterization, modification and application. INTECH Open Science.

Leupin, O. X., Wersin, P., Gimmi, T., Mettler, S., Rösli, U., Meier, O., Nussbaum, N. C.,Van Loon, L., Soler, J., Eikenberg, J., Fierz, T., van Dorp, F., Bossart, P., Pearson, F. J., Waber, H. N., Dewonck, S., Frutschi, M., Chaudagne, G., \& Kiczka, M. (2012). DR (Diffusion \& Retention) Experiment : Synthesis: Field activities, data and modelling. Mont Terri Technical Report, TR 11-01, 49 pp. Federal Office of Topography (swisstopo), Wabern, Switzerland. http://www.mont-terri.ch

Lin, L. C., \& Beuchat, L. R. (2007). Survival of Enterobacter sakazakii in infant cereal as affected by composition, water activity, and temperature. Food Microbiology, 24, 767-777.

Mauclaire, L., \& McKenzie, J. (2006a). PC Experiment: Microbial activity and identification within PC, PC-C porewaters. Mont Project Technical Note, TN 2006-61, 18 pp. Federal Office of Topography (swisstopo), Wabern, Switzerland. http://www. mont-terri.ch

Mauclaire, L., \& McKenzie, J. (2006b). PC and MA Experiments: Microbial activity and identification within PC, PC-C porewaters. Mont Terri Technical Note, TN 2006-62, 21 pp. Federal Office of Topography (swisstopo), Wabern, Switzerland. http:// www.mont-terri.ch

Mauclaire, L., \& McKenzie, J., Schippers, A. (2006). MA-experiment: Microbiological analysis of pore water samples from the PC and PC-C experiments in May 2006. Mont Terri Technical Note, TN 2006-56, 22 pp. Federal Office of Topography (swisstopo), Wabern, Switzerland. http://www.mont-terri.ch

Mauclaire, L., McKenzie, J. A., Schwyn, B., \& Bossart, P. (2007). Detection and cultivation of indigenous microorganisms in 
Mesozoic claystone core samples from the Opalinus Clay Formation (Mont Terri Rock Laboratory). Physics and Chemistry of the Earth, 32, 232-240.

Mazurek, M., Alt-Epping, P., Bath, A., Gimmi, T., \& Waber, H. N. (2009). Natural Tracer Profiles across Argillaceous Formations: The CLAYTRAC Project (p. 365). OECD Paris, France: Nuclear Energy Agency report.

Mazurek, M., Alt-Epping, P., Gimmi, T., Waber, \& H. N. (2007). Tracer profiles across argillaceous formations: A tool to constrain transport processes. In T. D. Bullen, \& Y.Wang (Eds.), Proceedings of the 12th International Symposium on Water-Rock Interaction, WRI-12, China 2007 volume 1 \& 2 (pp. 767-772). Taylor \& Francis Ltd.

Moll, H., Lütke, L., Bachvarova, V., Steudner, R., Geißler, A., Krawczyk-Bärsch, E., Selenska-Pobell, S., \& Bernhard, G. (2013). Microbial diversity in Opalinus Clay and interaction of dominant microbial strains with actinides. WissenschaftlichTechnische Berichte, HZDR-036, Helmholtz-Zentrum DresdenRosendorf, Dresden.

Moore, E. R. B., Tindall, B. J., Dos Santos, V. A. P. M., Pieper, D. H., Ramos, J.-L., \& Palleroni, N. J. (2006). Nonmedical: Pseudomonas. In M. Dworkin, S. Falkow, E. Rosenberg, K.-H Schleifer,K.-H., \& E. Stackebrandt, (Eds.), The Prokaryotes (pp. 646-703). New-York: Springer.

Moors, H., Cherkouk, A., Mysara, M., Bleyen, N., Boven, P., SelenskaPobell, S., \& Leys, N. (2013). BN Experiment: Intermediate results of the microbiological analyses. Mont Terri Technical Note, TN 2013-38, 68 pp. Federal Office of Topography (swisstopo), Wabern, Switzerland. http://www.mont-terri.ch

Moors, H., Geissler, A., Boven, P., Selenska-Pobell, S., \& Leys, N. (2012). BN Experiment: Intermediate results of the microbiological analyses. Mont Terri Technical Note, TN 2011-39, 27 pp. Federal Office of Topography (swisstopo), Wabern, Switzerland. http://www.mont-terri.ch

Moors, H., Mysara, M., Bleyen, N., Cherkouk, A., Boven, P., \& Leys, N. (2015). BN Experiment: Results of the microbiological analyses obtained during phase $19 \& 20$. Mont Terri Technical Note, TN 2015-72, 34 pp. Federal Office of Topography (swisstopo), Wabern, Switzerland. http://www.mont-terri.ch

Nakano, M., \& Kawamura, K. (2010). Estimating the corrosion of compacted bentonite by a conceptual model based on microbial growth dynamics. Applied Clay Science, 47, 43-50.

Poulain, S., Sergeant, C., Simonoff, M., Le Marrec, C., \& Altmann, S. (2008). Microbial investigations in Opalinus Clay, an argillaceous formation under evaluation as a potential host rock for a radioactive waste repository. Geomicrobiology Journal, 25, 240-249.

Ramamoorthy, S., Sass, H., Langner, H., Schumann, P., Kroppenstedt, R. M., Spring, S., et al. (2006). Desulfosporosinus lacus sp. nov., a sulfate-reducing bacterium isolated from pristine freshwater lake sediments. International Journal of Systematic and Evolutionary Microbiology, 56, 2729-2736.

Saddler, G. S., \& Bradbury, J. F. (2005). Xanthomonadaceae. In G. M. Garrity, D. J. Brenner, N. R. Krieg, \& J. T. Staley (Eds.),
Bergey's Manual of Systematic Bacteriology. New-York: Springer.

Senger R., Papafotiou A., \& Marschall, P. (2013). Gas related property distributions in the proposed host rock formations of the candidate siting regions in Northern Switzerland and in the Helvetic Zone. Nagra Arbeitsbericht, NAB 13-083, Nagra, Wettingen, Switzerland. http://www.nagra.ch

Spring, S., \& Rosenzweig, F. (2006). The genera Desulfitobacterium and Desulfosporosinus: taxonomy. In M. Dworkin, S. Falkow, E. Rosenberg, K.-H Schleifer,K.-H., \& E. Stackebrandt, (Eds.), The Prokaryotes (pp. 771-786). New-York: Springer.

Stroes-Gascoyne, S., Pedersen, K., Haveman, S. A., Daumas, S., Hamon, C. J., Arlinger, J., et al. (1997). Occurrence and identification of microorganisms in compacted clay-based buffer material designed for use in a nuclear fuel waste disposal vault. Canadian Journal of Microbiology, 43, 1133-1146.

Stroes-Gascoyne, S., Schippers, A., Schwyn, B., Poulain, S., Sergeant, C., Simonoff, M., et al. (2007). Microbial community analysis of Opalinus Clay drill core samples from the Mont Terri Underground Research Laboratory, Switzerland. Geomicrobiology Journal, 24, 1-17.

Stroes-Gascoyne, S., Sergeant, C., Schippers, A., Hamon, C. J., Nèble, S., Vesvres, M.-H., et al. (2011). Biogeochemical processes in a clay formation in situ experiment: Part D Microbial analyses - Synthesis of results. Applied Geochemistry, 26, 980-989.

Stroes-Gascoyne, S., Sergeant, C., Schippers, A., Hamon, C.J., Nèble, S., Vesvres, M.-H., Poulain, S., \& Le Marrec, C. (2008). Microbial analyses of PC water and overcore samples: Synthesis of results. Mont Terri Technical Note, TN 2006-69 30 pp. Federal Office of Topography (swisstopo), Wabern, Switzerland. http://www.mont-terri.ch

Stroes-Gascoyne, S., \& West, J. (1997). Microbial studies in the Canadian nuclear fuel waste management program. FEMS Microbiology Reviews, 20, 573-590.

Susina, N. E., Mulyukin, A. L., Kozlova, A. N., Shorokhova, A. P., Dmitriev, V. V., Barinova, E. S., et al. (2004). Ultrastructure of resting cells of some non-spore-forming bacteria. Microbiology, $73,435-447$.

Takeuchi, M., Komai, T., Hanada, S., Tamaki, H., Tanabe, S., Miyachi, Y., et al. (2009). Bacterial and Archaeal 16S rRNA Genes in late Pleistocene to Holocene muddy sediments from the Kanto Plain of Japan. Geomicrobiology Journal, 26, 104-118.

Xie, C.-H., \& Yokota, A. (2005). Pleomorphomonas oryzae gen. nov., sp. nov., a nitrogen-fixing bacterium isolated from paddy soil of Oryza sativa. International Journal of Systematic and Evolutionary Microbiology, 55, 1233-1237.

Yoon, J. H., Kang, S. J., Park, S., Lee, S. Y., \& Oh, T. K. (2007). Reclassification of Aquaspirillum itersonii and Aquaspirillum peregrinum as Novispirillum itersonii gen. nov., comb. nov. and Insolitispirillum peregrinum gen. nov., comb. nov. International Journal of Systematic and Evolutionary Microbiology, 57, 2830-2835. 